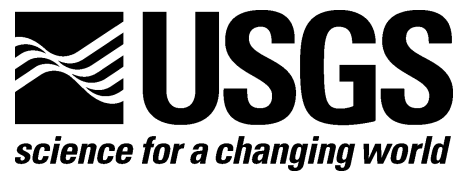

\title{
Major- and Trace-Element Concentrations in Soils from Northern California: Results from the Geochemical Landscapes Project Pilot Study
}

By Jean M. Morrison, Martin B. Goldhaber, JoAnn M. Holloway, and David B. Smith

Open-File Report 2008-1306

U.S. Department of the Interior

U.S. Geological Survey 


\section{U.S. Department of the Interior DIRK KEMPTHORNE, Secretary}

\section{U.S. Geological Survey Mark D. Myers, Director}

U.S. Geological Survey, Reston, Virginia: 2008

For product and ordering information:

World Wide Web: http://www.usgs.gov/pubprod

Telephone: 1-888-ASK-USGS

For more information on the USGS-the Federal source for science about the Earth, its natural and living resources, natural hazards, and the environment:

World Wide Web: http://www.usgs.gov

Telephone: 1-888-ASK-USGS

Suggested citation:

Morrison, J.M., Goldhaber, M.B., Holloway, J.M., and Smith, D.B., 2008, Major- and TraceElement Concentrations in Soils from Northern California: Results from the Geochemical Landscapes Project Pilot Study: U.S. Geological Survey Open-File Report, 2008-1306, 7 p.

Any use of trade, product, or firm names is for descriptive purposes only and does not imply endorsement by the U.S. Government.

Although this report is in the public domain, permission must be secured from the individual copyright owners to reproduce any copyrighted material contained within this report.

The U.S. Geological Survey cannot verify the accuracy of the data contained within the electronic files of this report if the data were obtained from a source other than the U.S. Geological Survey. 


\section{Contents}

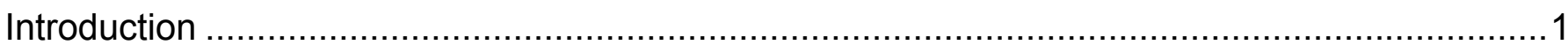

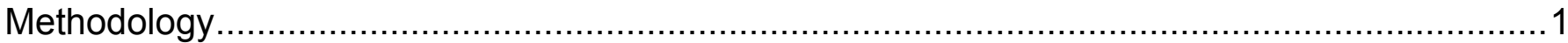

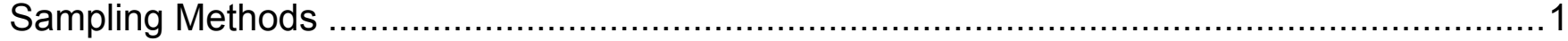

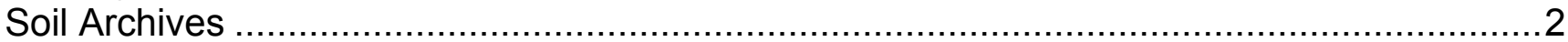

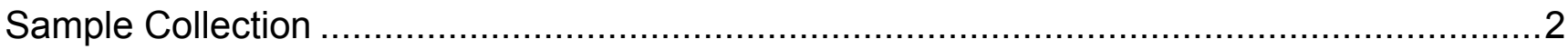

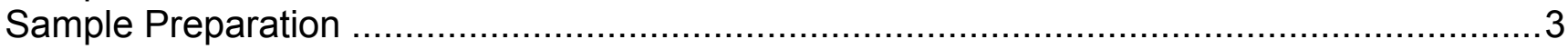

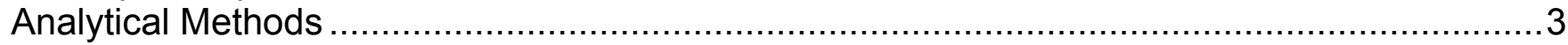

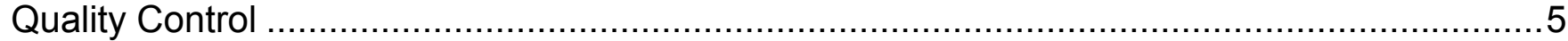

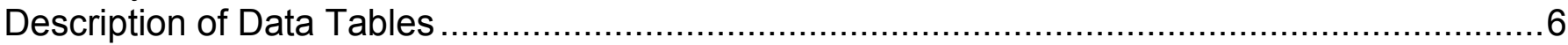

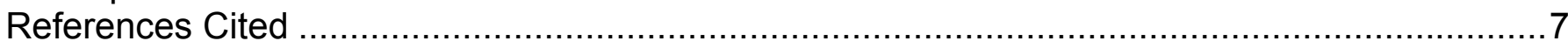

\section{Figures}

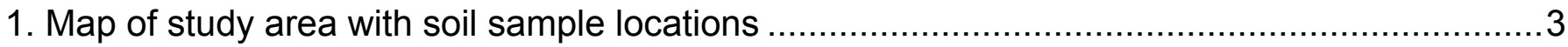

\section{Tables}

1. Elements and their upper and lower reporting limits determined by 4-acid

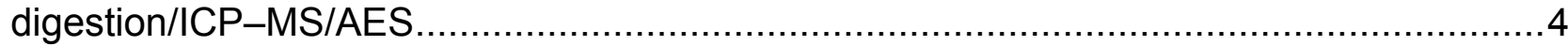

2. Elements and their upper and lower reporting limits determined by lithium metaborate fusion followed by ICP-AES 6

3. Major- and trace-element data for NURE archived soils Web links on page 6

4. Major- and trace-element data for UC Davis archived soils Web links on page 6

5. Major- and trace-element data for El Dorado National Forest archived soils

Web links on page 6

6. Major- and trace-element data for soils collected from the Geochemical Landscapes Project. Web links on page 6 


\title{
Major- and Trace-Element Concentrations in Soils from Northern California: Results from the Geochemical Landscapes Project Pilot Study
}

\author{
By Jean M. Morrison, Martin B. Goldhaber, JoAnn M. Holloway, and David B. Smith
}

\section{Introduction}

In 2004, the U.S. Geological Survey (USGS), the Geological Survey of Canada (GSC), and the Mexican Geological Survey (Servicio Geológico Mexicano, or SGM) initiated pilot studies in preparation for a soil geochemical survey of North America called the Geochemical Landscapes Project. The purpose of this project is to provide a better understanding of the variability in chemical composition of soils in North America. The data produced by this survey will be used to construct baseline geochemical maps for regions within the continent. Two initial pilot studies were conducted: (1) a continental-scale study involving a north-south and east-west transect across North America and (2) a regional-scale study. The pilot studies were intended to test and refine sample design, sampling protocols, and field logistics for the full continental soils geochemical survey. Smith and others (2005) reported the results from the continental-scale pilot study. The regional-scale California study was designed to represent more detailed, higher resolution geochemical investigations in a region of particular interest that was identified from the lowsample-density continental-scale survey.

A $20,000-\mathrm{km}^{2}$ area of northern California (fig. 1), representing a wide variety of topography, climate, and ecoregions, was chosen for the regional-scale pilot study. This study area also contains diverse geology and soil types and supports a wide range of land uses including agriculture in the Sacramento Valley, forested areas in portions of the Sierra Nevada, and urban/suburban centers such as Sacramento, Davis, and Stockton. Also of interest are potential effects on soil geochemistry from historical hard rock and placer gold mining in the foothills of the Sierra Nevada, historical mercury mining in the Coast Range, and mining of base-metal sulfide deposits in the Klamath Mountains to the north. This report presents the major- and trace-element concentrations from the regional-scale soil geochemical survey in northern California.

\section{Methodology}

\section{Sampling Methods}

Four different collections of soil samples were analyzed in this study. In addition to the collection of new soil samples, archived soil samples were obtained from three different sources. Using previously collected samples provided an opportunity to obtain soil geochemical data at a high spatial density, which guided the choice of sampling locations for the 2003-2007 effort. 
Analyzing soil archives also has the potential to provide information about changes in geochemical trends over time.

\section{Soil Archives}

\section{National Uranium Resource Evaluation (NURE)}

Stream sediment and soil samples were collected on a national scale from the late 1970s to early 1980s as part of the U.S. Department of Energy's National Uranium Resource Evaluation (NURE). In 1980, the NURE program conducted a focused study called the Hydrogeochemical and Stream Sediment Reconnaissance (HSSR), which collected soils using a 1-km-grid spacing in the 1:250,000-scale Sacramento quadrangle (Smith, 1997). At each site, the top 5 centimeters of plant material and soil was scraped off and a 10-15-cm depth sample was collected with a hand spade. Soil samples from at least 10 locations at least $10 \mathrm{ft}$ apart were combined as composite samples and sieved into two fractions; 40-18 mesh (400-1,000 $\mu \mathrm{m})$ and $<40$ mesh (Price and Jones, 1979). Splits of the sieved soil samples were stored in plastic jars at the U.S. Geological Survey in Denver, Colorado. Our study submitted 1,293 archived <40-mesh NURE soils collected in the Sacramento quadrangle (fig. 1) for chemical analysis.

\section{Davis Archive}

The U.S. Department of Agriculture (USDA) Soil Conservation Service (now National Resources Conservation Service, NRCS) completed a soil survey of benchmark soils in California. The soils were collected as type pedons by soil series and were collected by soil horizon (fig. 1). The $<2-\mathrm{mm}$-size fraction was archived in plastic vials in a warehouse at the University of California - Davis. Splits of archived samples from 98 soil profiles were taken for chemical analysis as described herein. Further information on soil series and type pedon locations is available on the Natural Resources Conservation Service-Data Mart Web site (http://soildatamart.nrcs.usda.gov).

\section{El Dorado National Forest}

A third archive was collected for a soil survey conducted by the USDA Forest Service in the El Dorado National Forest in 1978-79. Fifty samples from 12 soil profiles were provided by the USDA Forest Service, and the $<2-\mathrm{mm}$-size fraction was chemically analyzed.

\section{Sample Collection}

Additional soil samples were collected as part of the Geochemical Landscapes Project between 2003 and 2007 from the Coast Range along transects following Cache and Putah Creeks, from the western Sierra Nevada foothills and throughout the Sacramento Valley (fig. 1). Although samples were generally collected by soil horizon, only surface samples were collected at some locations. The $<2-\mathrm{mm}$ fraction was collected in the field using a stainless-steel sieve except for some indurated clay-rich soils. These were collected as bulk samples and later disaggregated using an agate mortar and pestle and sieved to $<2 \mathrm{~mm}$ in the laboratory. A comparison study of duplicate field- and laboratory-sieved samples showed no significant difference in soil chemistry. Samples collected for major- and trace-element analyses were stored in plastic Whirlpak® bags with a split for mercury analyses stored in trace-element-free amber glass jars. 


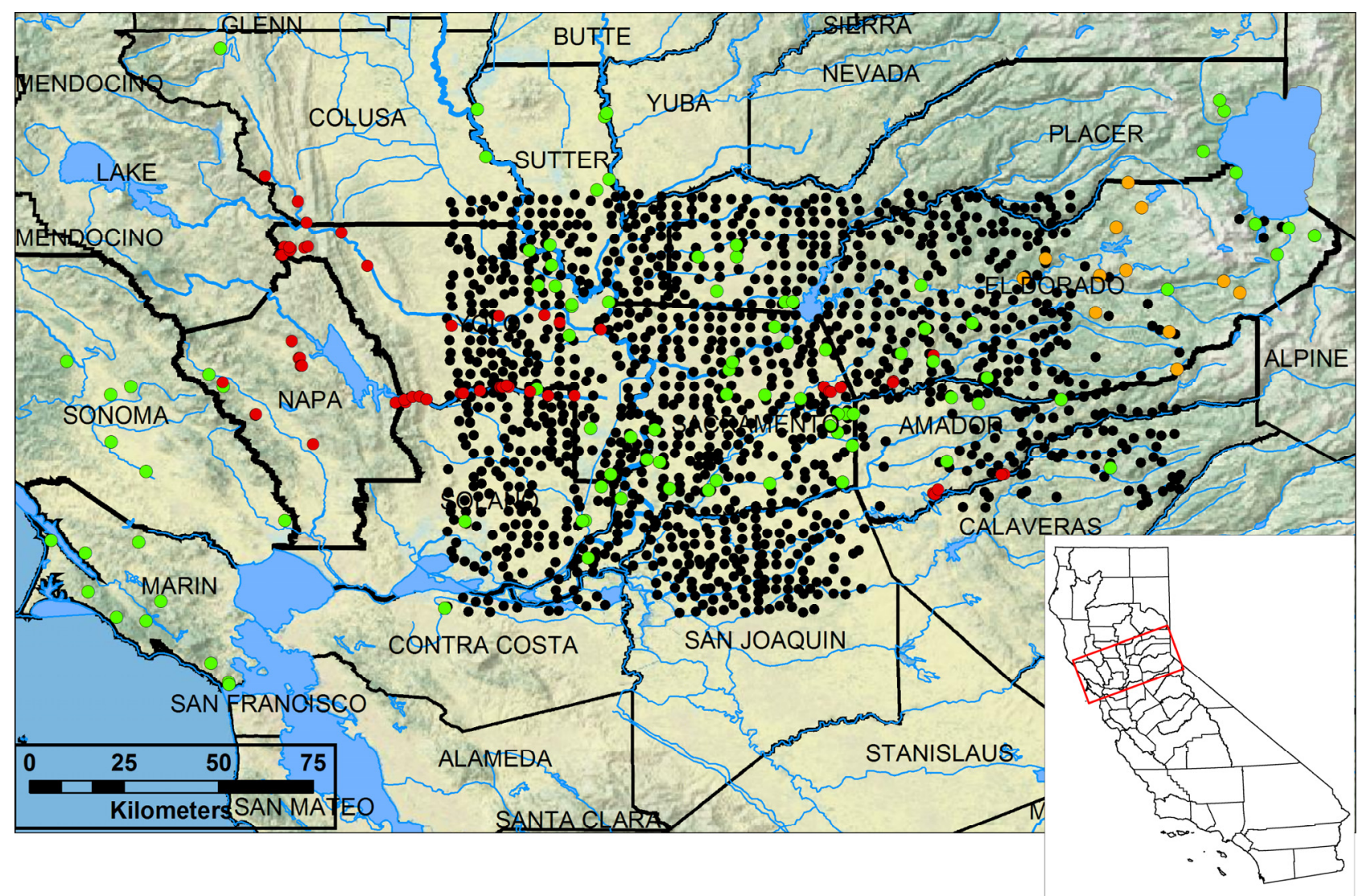

Figure 1. Map of study area in California with soil sample locations. Circles indicate the locations of soil samples: Black=NURE surface soil samples; green=type pedons from the Davis archive; orange=El Dorado Forest samples; and red=soil samples collected from 2004-2007 as part of this study. The inset map shows the outline of California with the red box indicating the extent of the study area.

\section{Sample Preparation}

Newly collected samples were dried at $25^{\circ} \mathrm{C}$ in a convection oven. All soil samples, including archived samples, were ground to $<110$-mesh $(150 \mu \mathrm{m})$ in a shatter box prior to chemical analyses (modification of Peacock, 2002).

\section{Analytical Methods}

Forty-two elements were determined by a 4-acid digestion $\left(\mathrm{HNO}_{3}, \mathrm{HCl}, \mathrm{HF}, \mathrm{HClO}_{4}\right)$ followed by inductively coupled plasma-atomic emission spectrometry (ICP-AES) and inductively coupled plasma-mass spectrometry (ICP-MS) (modification of Briggs and Meier, 2002). The analyses were performed by SGS Minerals in Toronto, Ontario, Canada, under contract with the U.S. Geological Survey. 
Table 1. Elements and their lower and upper reporting limits determined by 4-acid digestion/ICP-MS/AES (SGS Minerals, unpub. Data, 2008).

[mg/kg, milligrams per kilogram soil; \%, weight percent]

\begin{tabular}{llllll}
\hline Element $^{1}$ & Lower limit & Upper limit & Element $^{1}$ & Lower limit & Upper limit \\
\hline Aluminum, $\mathrm{Al}$ & $0.01 \%$ & $15 \%$ & Lanthanum, La & $0.5 \mathrm{mg} / \mathrm{kg}$ & $0.1 \%$ \\
Calcium, Ca & $0.01 \%$ & $15 \%$ & Lithium, Li & $1 \mathrm{mg} / \mathrm{kg}$ & $5 \%$ \\
Iron, Fe & $0.01 \%$ & $15 \%$ & Manganese, Mn & $5 \mathrm{mg} / \mathrm{kg}$ & $1 \%$ \\
Potassium, K & $0.01 \%$ & $15 \%$ & Molybdenum, Mo & $0.05 \mathrm{mg} / \mathrm{kg}$ & $1 \%$ \\
Magnesium, Mg & $0.01 \%$ & $15 \%$ & Niobium, Nb & $0.1 \mathrm{mg} / \mathrm{kg}$ & $0.1 \%$ \\
Sodium, Na & $0.01 \%$ & $15 \%$ & Nickel, Ni & $0.5 \mathrm{mg} / \mathrm{kg}$ & $1 \%$ \\
Phosphorus, P & $50 \mathrm{mg} / \mathrm{kg}$ & $1 \%$ & Lead, Pb & $0.5 \mathrm{mg} / \mathrm{kg}$ & $1 \%$ \\
Titanium, Ti & $0.01 \%$ & $15 \%$ & Rubidium, Rb & $0.2 \mathrm{mg} / \mathrm{kg}$ & $1 \%$ \\
Silver, $\mathrm{Ag}$ & $1 \mathrm{mg} / \mathrm{kg}$ & $10 \mathrm{mg} / \mathrm{kg}$ & Sulfur, S & $0.01 \%$ & $5 \%$ \\
Arsenic, $\mathrm{As}$ & $1 \mathrm{mg} / \mathrm{kg}$ & $1 \%$ & Antimony, Sb & $0.05 \mathrm{mg} / \mathrm{kg}$ & $1 \%$ \\
Barium, Ba & $5 \mathrm{mg} / \mathrm{kg}$ & $1 \%$ & Scandium, Sc & $0.1 \mathrm{mg} / \mathrm{kg}$ & $0.1 \%$ \\
Beryllium, Be & $0.1 \mathrm{mg} / \mathrm{kg}$ & $100 \mathrm{mg} / \mathrm{kg}$ & Tin, Sn & $0.1 \mathrm{mg} / \mathrm{kg}$ & $0.1 \%$ \\
Bismuth, Bi & $0.04 \mathrm{mg} / \mathrm{kg}$ & $1 \%$ & Strontium, Sr & $0.5 \mathrm{mg} / \mathrm{kg}$ & $1 \%$ \\
Cadmium, Cd & $0.1 \mathrm{mg} / \mathrm{kg}$ & $1 \%$ & Tellurium, Te & $0.1 \mathrm{mg} / \mathrm{kg}$ & $0.05 \%$ \\
Cerium, Ce & $0.05 \mathrm{mg} / \mathrm{kg}$ & $0.1 \%$ & Thallium, Tl & $0.1 \mathrm{mg} / \mathrm{kg}$ & $1 \%$ \\
Cobalt, Co & $0.1 \mathrm{mg} / \mathrm{kg}$ & $1 \%$ & Thorium, Th & $0.2 \mathrm{mg} / \mathrm{kg}$ & $1 \%$ \\
Chromium, Cr & $1 \mathrm{mg} / \mathrm{kg}$ & $1 \%$ & Uranium, U & $0.1 \mathrm{mg} / \mathrm{kg}$ & $1 \%$ \\
Cesium, Cs & $0.05 \mathrm{mg} / \mathrm{kg}$ & $0.1 \%$ & Vanadium, V & $1 \mathrm{mg} / \mathrm{kg}$ & $1 \%$ \\
Copper, Cu & $0.5 \mathrm{mg} / \mathrm{kg}$ & $1 \%$ & Tungsten, W & $0.1 \mathrm{mg} / \mathrm{kg}$ & $1 \%$ \\
Gallium, Ga & $0.05 \mathrm{mg} / \mathrm{kg}$ & $500 \mathrm{mg} / \mathrm{kg}$ & Yttrium, Y & $0.1 \mathrm{mg} / \mathrm{kg}$ & $1 \%$ \\
Indium, In & $0.02 \mathrm{mg} / \mathrm{kg}$ & $0.05 \%$ & Zinc, Zn & $1 \mathrm{mg} / \mathrm{kg}$ & $1 \%$ \\
\hline
\end{tabular}

${ }^{1}$ Data are deemed acceptable if recovery for all 42 elements is \pm 15 percent at five times the Lower Limit of Determination (LOD) and the calculated Relative Standard Deviation (RSD) of the duplicate samples is no greater than 15 percent.

Additional analysis for 16 elements that include some of the more refractory elements was completed using lithium metaborate fusion/16-element ICP-AES. The procedure fused a 100-mg split of homogenized sample of ground soil/rock with lithium metaborate in a graphite crucible, which was then dissolved in nitric acid. The solutions were aspirated into the ICP through a highsolids nebulizer and the elemental emission signal was measured simultaneously for all 16 elements (SGS Minerals). These analyses were also performed by the USGS contract laboratory, SGS Minerals.

Additional analyses were obtained on a subset of samples with analyses performed by SGS Laboratories. Selenium and antimony were analyzed using hydride generation-atomic absorption 
spectrometry (modification of Hageman and others, 2002). The lower and upper reporting limits for selenium, respectively, were 0.2 and $4 \mathrm{mg} / \mathrm{kg}$ and for antimony were 0.6 and $20 \mathrm{mg} / \mathrm{kg}$. Mercury was analyzed by cold-vapor atomic absorption spectroscopy based on a modification of USEPA method 7471A (United States Environmental Protection Agency, 1994) with a lower reporting limit of $0.02 \mathrm{mg} / \mathrm{kg}$. Total sulfur was analyzed by combustion with the lower and upper reporting limits 0.05 and 35 percent (modification of Brown and Curry, 2002c). Total carbon was determined by an automated carbon analyzer with reporting limits between 0.05 and 30 percent (modification of Brown and Curry, 2002a). Inorganic carbon was determined by coulometric titration with upper and lower reporting limits of 0.04 percent and 50 percent, respectively (modification of Brown and others, 2002b). Organic carbon was determined by subtraction of total and inorganic carbon values.

Total carbon, organic carbon, and total nitrogen were analyzed for samples collected in April and May 2004 by pyrolysis at $980^{\circ} \mathrm{C}$ (Exeter 440 Elemental Analyzer) at the Boulder, U.S. Geological Survey National Research Program laboratories in Boulder, Colorado. Organic carbon was determined on soils pretreated with $1 \mathrm{~N} \mathrm{HCl}$ to remove carbonate minerals. All samples were run in duplicate with standards placed every 12 samples to check for instrument drift. An external standard soil was analyzed at the beginning, middle, and end of each run.

Samples collected after May 2004 had total nitrogen analyzed by pyrolysis (LECO TruSpec $\mathrm{CN}$ furnace at an operating temperature of $950^{\circ} \mathrm{C}$ ) at the Colorado State University (CSU) Soil, Water \& Plant Testing Laboratory (Fort Collins, Colorado). Total carbon and nitrogen were both analyzed by pyrolysis at this facility for samples collected in June 2007 . The instrument was calibrated to three blanks $(<0.001$ percent $)$ and a standard sample $( \pm 5$ percent of the mean $\mathrm{C}$ and $\mathrm{N}$ concentration). Instrument drift was checked every 25 samples to ensure that the standard curve had not drifted. Analytical duplicates were run at the frequency of 10 percent (J.R.Self, Fort Collins Colorado State University Soil, Water \& Plant Testing Laboratory, written commun., 2008).

\section{Quality Control}

Standard reference materials (SRMs) were submitted for quality control for all analyses except the carbon and nitrogen analyses completed at the CSU and USGS Boulder laboratories. Standards were analyzed at the rate of one SRM for every 10 samples. Standard reference materials SRM 2709 (National Institute of Standards and Technology, NIST) and DGPM-1 (USGS) as well as USGS-produced SRMs were used to monitor the digestion procedure (Wilson and Wolf, 2007). Sample duplicates were submitted at a rate of one for every 20 samples, and analytical duplicate samples were analyzed at the frequency of one duplicate for every 20 samples. Data are deemed acceptable if they are \pm 15 percent at five times the lower limit of determination and the calculated relative standard deviation (RSD) of duplicate samples is no greater than 15 percent. 
Table 2. Elements and their lower and upper reporting limits determined by lithium metaborate fusion followed by ICP-AES (SGS Minerals, unpub. data, 2008).

[mg/kg, milligrams per kilogram soil; \%, weight percent]

\begin{tabular}{lcc}
\hline \multicolumn{1}{c}{ Element $^{1}$} & Lower limit & Upper limit \\
\hline Aluminum, $\mathrm{Al}$ & $0.01 \%$ & $15 \%$ \\
Barium, $\mathrm{Ba}$ & $10 \mathrm{mg} / \mathrm{kg}$ & $10 \%$ \\
Calcium, $\mathrm{Ca}$ & $0.01 \%$ & $10 \%$ \\
Chromium, $\mathrm{Cr}$ & $0.01 \%$ & $10 \%$ \\
Iron, Fe & $0.01 \%$ & $30 \%$ \\
Magnesium, $\mathrm{Mg}$ & $0.01 \%$ & $30 \%$ \\
Manganese, $\mathrm{Mn}$ & $0.01 \%$ & $10 \%$ \\
Niobium, $\mathrm{Nb}$ & $10 \mathrm{mg} / \mathrm{kg}$ & $10 \%$ \\
Phosphorus, $\mathrm{P}$ & $0.01 \%$ & $25 \%$ \\
Potassium, $\mathrm{K}$ & $0.01 \%$ & $25 \%$ \\
Silicon, $\mathrm{Si}$ & $0.01 \%$ & $30 \%$ \\
Sodium, $\mathrm{Na}$ & $0.01 \%$ & $30 \%$ \\
Strontium, $\mathrm{Sr}$ & $10 \mathrm{mg} / \mathrm{kg}$ & $10 \%$ \\
Titanium, $\mathrm{Ti}$ & $0.01 \%$ & $25 \%$ \\
Yttrium, Y & $10 \mathrm{mg} / \mathrm{kg}$ & $10 \%$ \\
Zirconium, $\mathrm{Zr}$ & $10 \mathrm{mg} / \mathrm{kg}$ & $10 \%$ \\
\hline
\end{tabular}

${ }^{1}$ Data are deemed acceptable if they are \pm 15 percent at 5 times the lower limit of detection, and the calculated RSD of duplicate samples is no greater than 15 percent.

\section{Description of Data Tables}

Data are reported in four tables. Table 3.xls, Table 4.xls, and Table 5.xls contain data from the NURE, Davis, and El Dorado Forest soil archives, respectively. Table 6.xls contains all data collected by the Geochemical Landscapes Project from 2004 to 2007. Element concentrations are reported with column headings denoting the method: ICP 16 is the 16-element determination by lithium metaborate fusion/ICP-MS; ICP 42 is the 42-element determination by 4-acid digestion/ICP-MS; hydride is antimony and selenium determination by hydride generation; CVAA Hyd reports mercury concentrations by cold vapor-atomic absorption spectroscopy. Unit qualifiers are in weight percent $(\%)$ or $\mathrm{mg} / \mathrm{kg}$. Cells labeled ND indicate that the element was not determined, and cells labeled NA indicate that information was not available. 


\section{References Cited}

Briggs, P.H., and Meier, A.L., 2002, The determination of forty-two elements in geological materials by inductively coupled plasma-mass spectrometry: U.S. Geological Survey OpenFile Report 02-223-I, p. 1-14, http://pubs.usgs.gov/of/2002/ofr-020223/I20NAWQAPlus_M.pdf

Brown, Z.A., and Curry, K.J., 2002a, Total carbon by combustion: U.S. Geological Survey OpenFile Report 2002-223-R, p. 1-4, http://pubs.usgs.gov/of/2002/ofr-020223/R10TotalCarbon_M.pdf

Brown, Z.A., Papp, C., Brandt, E., and Aruscavage, P., 2002b, Carbonate carbon by coulometric titration: U.S. Geological Survey Open-File Report 2002-223-S, p. 1-6, http://pubs.usgs.gov/of/2002/ofr-02-0223/S08CarbonateCarbon_S.pdf.

Brown, Z.A., and Curry, K.J., 2002c, Total sulfur by combustion: U.S. Geological Survey OpenFile Report 2002-223-Q, p. 1-4, http://pubs.usgs.gov/of/2002/ofr-02-0223/Q25TotS_M.pdf

Hageman, P.L., Brown, Z.A., and Welsch, E., 2002, Arsenic and selenium by flow injection or continuous flow-hydride generation-atomic absorption spectrometry: U.S. Geological Survey Open-File Report 2002-223-L, p. 1-9, http://pubs.usgs.gov/of/2002/ofr-020223/L06AS24Se_M.pdf

Peacock, T.R., 2002, Soil sample preparation: U.S. Geological Survery Open-File Report 2002223-A3, p. 1-6, http://pubs.usgs.gov/of/2002/ofr-02-0223/A3SoilPrep_M.pdf

Price, V., and Jones, P.L., 1979, Training manual for water and sediment geochemical reconnaissance: E.I. du Pont de Nemours \& Co., Savannah River Laboratory, Aiken, S.C., SRL Internal Doc. DPST-79-219, U.S. Department of Energy, Grand Junction, Colo.

Smith, D.B., Cannon, W.F., Woodruff, L.G., Garrett, R.G., Klassen, R., Kilburn, J.E., Horton, J.D., King, H.D., Goldhaber, M.B., and Morrison, J.M., 2005, Major- and trace-element concentrations in soils from two continental-scale transects of the United States and Canada: U.S. Geological Survey Open-File Report 2005-1253, http://pubs.usgs.gov/of/2005/1253/pdf/OFR1253.pdf

Smith, S.M., 1997, Sacramento Quadrangle NURE HSSR Study: U.S. Geological Survey OpenFile Report 97-492, http://pubs.usgs.gov/of/1997/ofr-97-0492/quad/q_sacram.htm

U.S. Environmental Protection Agency, 1994, Method 7471A, Revision 1 Mercury in solid or semisolid waste: EPA SW-846, 1994, 7 p.

USDA Forest Service, undated document, Soil Survey Eldorado National Forest California: U.S. Department of Agriculture Forest Service, 000104, p. 1-100.

Wilson, S.A., and Wolf, R.E., 2007, USGS Reference Materials Program: U.S. Geological Survey Fact Sheet 2007-3056, http://pubs.usgs.gov/fs/2007/3056/pdf/fs07-3056_508.pdf 